\title{
Synthesis of stabilized zirconia without dopants
}

\section{(Sintese de zircônia estabilizada sem dopantes)}

\author{
R. C. Pessoa ${ }^{1}$, M. Cerqueira ${ }^{1}$, R. S. Nasar ${ }^{1}$, I. V. P. Yoshida ${ }^{2}$ \\ ${ }^{1}$ Departamento de Química, UFRN, Natal, RN 59072-970 \\ ${ }^{2}$ Instituto de Química, Unicamp, Campinas, SP 13084-971 \\ nasar@terra.com.br
}

\begin{abstract}
$\mathrm{ZrO}_{2}-\mathrm{SiO}_{2}$ powders were synthesized through Pechini's method starting with $\mathrm{D}_{4} \mathrm{Vi}$, PMS and zirconium citrate. The complex polymer was decomposed to form different phases at high temperatures. During the resin decomposition, the phase transformation from monoclinic to tetragonal zirconia was detected by thermal analysis. The crystallization and the diffusion process of $\mathrm{Si}$ and $\mathrm{Zr}$ were analyzed by X-ray diffraction, XRD, scanning electron microscopy and microanalysis by EDS. Tetragonal zirconia at $1000^{\circ} \mathrm{C}$, monoclinic zirconia at $1200^{\circ} \mathrm{C}$ and monoclinic zirconia with cristobalite silica from $1300^{\circ}$ to $1400^{\circ} \mathrm{C}$ were formed. From $1000^{\circ} \mathrm{C}$ to $1300^{\circ} \mathrm{C}$ a diffuse amorphous band was related to the silica phase. The mapping of $\mathrm{K}_{\alpha}$ line of $\mathrm{Zr}$ and Si showed low diffusion of $\mathrm{Si}$ into the $\mathrm{ZrO}_{2}$ structure. The kinetics of crystallization formed macroparticles of silica and small particles of zirconia. A diffusion interface between $\mathrm{SiO}_{2}$ and $\mathrm{ZrO}_{2}$ to form $\mathrm{ZrSiO}_{4}$ phase was not observed, confirmed by XRD.
\end{abstract}

Keywords: Pechini method, zirconia stabilization, EDS microanalysis.

\section{Resumo}

Foram sintetizados através do método Pechini pós de $\mathrm{ZrO}_{2}-\mathrm{SiO}_{2}$ iniciando com $\mathrm{D}_{4}$ Vi, PMS e citrato de zircônio. O polímero complexo foi decomposto para formar diferentes fases em altas temperaturas. Durante a decomposição da resina foi detectado a transformação de fase monoclínica tetragonal por análise térmica. A cristalização e o processo de difusão do Si e do Zr foi analisado por difração de raios X, microscopia eletrônica de varredura e microanálise por EDS. Foi formada zircônia tetragonal em $1000{ }^{\circ} \mathrm{C}$, zircônia monoclínica em $1200{ }^{\circ} \mathrm{C}$ e zircônia monoclínica com sílica cristobalita de $1300^{\circ} \mathrm{C}$ até $1400{ }^{\circ} \mathrm{C}$. Entre 1000 e $1300^{\circ} \mathrm{C}$ foi relacionada uma banda amorfa difusa de fase sílica. O mapeamento das linhas $K_{a}$ do $\mathrm{Zr}$ e do Si demonstraram baixa difusão de Si na estrutura do $\mathrm{ZrO}_{2}$. A cinética de cristalização formou macro-partículas de sílica e pequenas partículas de zircônia. Não foi observada a interface de difusão entre $\mathrm{SiO}_{2}$ e $\mathrm{ZrO}_{2}$ confirmada por difração de raios $\mathrm{X}$.

Palavras-chave: método de Pechini, estabilização da zircônia, microanálise por EDS.

\section{INTRODUCTION}

Considerable research has been done on the synthesis of ceramic materials based on zirconia. Different synthesis methods such as co-precipitation, sol-gel process and organic precursor have been developed for zirconia stabilization. The stabilization effect occurs with additions of dopants like $\mathrm{MgO}, \mathrm{CaO}, \mathrm{CeO}_{2}, \mathrm{Y}_{2} \mathrm{O}_{3}$ and oxides based on rare earths.

According to several authors the mixture of precursors of $\mathrm{ZrO}_{2}$ and $\mathrm{SiO}_{2}$ led to $\mathrm{ZrSiO}_{4}$ (zircon) phase formation [13]. Although difficult, the preparation of the homogeneous zircon phase has already been the subject of several research papers [4-6]. Veytizou et alii [7] synthesized zircon starting from amorphous precursors powder by the sol-gel method. The powder was prepared with tetraethoxysilane (TEOS), $\mathrm{Si}\left(\mathrm{OC}_{2} \mathrm{H}_{5}\right)_{4}$ and zirconyl nitrate hydrate, $\mathrm{ZrO}\left(\mathrm{NO}_{3}\right)_{2} \cdot 6 \mathrm{H}_{2} \mathrm{O}$. Aguilar et alii [8] studied the crystallization of zircon with a synthesis with TEOS and zirconium propoxide. Below $1200{ }^{\circ} \mathrm{C}$ tetragonal zirconia and amorphous silica and zircon were formed for several compositions. Shi et alii [9] synthesized ultrafine zircon powder with high purity starting with a $\mathrm{ZrOCl}_{2}$ solution and fumed silica. The zircon precursor gels were prepared by a wet chemical precipitation and the gel were seeded with zircon sand powder. High chemical homogeneity and particle size from 0.2 to $0.3 \mu \mathrm{m}$ were obtained at high calcination temperature. The use of conventional technique for $\mathrm{ZrSiO}_{4}$ synthesis does not led to homogeneous phase and favors an abnormal grain growth during the calcination or the sintering process.

Additions of silicon into the zirconia structure do not produce vacancies. According to some authors the isovalent substitution of zirconium by silicon caused dispersion of silicon into the zirconia particles and does not favor the stabilization effect of structure. Silicon diffusion caused an interface formation and growth the $\mathrm{ZrSiO}_{4}(\mathrm{ZS})$ phase. However, in any case the tetragonal and/or cubic phase of zirconia takes place without the formation of the SZ phase.

Among several methods of synthesis, the polymeric precursor process led to obtain high powder surface area and chemical homogeneity at molecular level. The objective of the present work was an investigation of the phase formation during decomposition of the polymeric precursors based on 
silica and zirconia and to verify the diffusion process of silicon into the zirconia structure. The synthesis method was the polymeric precursor that produced powders with high surface area and homogeneity of phases.

\section{EXPERIMENTAL}

Reagents based on $\mathrm{Zr}$ and $\mathrm{Si}$ were mixed by using the polymeric precursor process, Table I.

Table I - Purity and origin of reagents.

[Tabela I - Pureza e origem dos reagentes.]

\begin{tabular}{lcl}
\hline \multicolumn{1}{c}{ Name } & $\begin{array}{c}\text { Purity } \\
(\%)\end{array}$ & \multicolumn{1}{c}{ Origin } \\
\hline IV Zirconium Butoxide & 99.2 & Aldrich \\
Citric Acid & 99.3 & Vetec \\
Ethyleneglicol & 99.0 & Vetec \\
Tetrametiltetravinilciclotetrasiloxane & 99.6 & Dow Corning \\
$\left(\mathrm{D}_{4}\right.$ Vi) & 99.8 & Dow Corning \\
Polymetilsiloxane (PMS) & & \\
\hline
\end{tabular}

Citric acid was mixed to IV-zirconium butoxide in water and homogeneized at $90{ }^{\circ} \mathrm{C}$ for $6 \mathrm{~h}$. Ethyleneglycol was added to the solution and stirred for $2 \mathrm{~h}$. The zirconium citrate was mixed by stirring to $\mathrm{D}_{4} \mathrm{~V}_{\mathrm{i}}$ and PMS according to Table II.

Table II - Concentration of reagents in the mixture of compounds.

[Tabela II - Concentração dos reagentes na mistura dos compostos.]

\begin{tabular}{cccc}
\hline Concentration & $\begin{array}{c}\text { Zr Resin } \\
(\mathrm{g})\end{array}$ & $\begin{array}{c}\mathrm{D}_{4} \mathrm{Vi} \\
(\mathrm{g})\end{array}$ & $\begin{array}{c}\text { PMS } \\
(\mathrm{g})\end{array}$ \\
\hline $\mathrm{C} 1$ & 30 & 75 & 5 \\
$\mathrm{C} 2$ & 40 & 65 & 5 \\
$\mathrm{C} 3$ & 50 & 55 & 5 \\
\hline
\end{tabular}

The polymeric resin was calcined from 100 to $1400{ }^{\circ} \mathrm{C}$ several times. The powder was deagglomerated in agate mortar and sieved at 325 meshes.

The powder was characterized by Fourier transform infrared spectroscopy, FTIR, in a Bomem B100 equipment with $\mathrm{KBr}$ pellets, with a resolution of $4 \mathrm{~cm}^{-1}$ from 4000 to $400 \mathrm{~cm}^{-1}$. DTA analysis was performed in a TA instruments model 2910 with a heating rate of $10^{\circ} \mathrm{C} /$ min under oxygen. The powder was analyzed by $\mathrm{X}$ - ray diffraction in a Shimadzu XRD 6000 diffractometer with $\mathrm{CuK} \alpha$ radiation, 1.5418 $\AA$, and $2 \theta$ from $10^{\circ}$ to $80^{\circ}$. The powder was analyzed by scanning electron microscopy, SEM, and energy dispersive spectroscopy, EDS, with a JEOL-JSM T-300 microscope with an acceleration voltage of $20 \mathrm{kV}$.

\section{RESULTS AND DISCUSSION}

Fig. 1 shows the DTA curves of C1, C2 and C3 concentrations with an endothermic reaction related to water release near $100^{\circ} \mathrm{C}$ (adsorbed water) and an endothermic peak due to release of structural water from 180 to $200^{\circ} \mathrm{C}$. The decomposition of polymer takes place with an endothermic peak from 400 to $800^{\circ} \mathrm{C}$. Near $1200^{\circ} \mathrm{C}$ an endothermic peak is related to monoclinic to tetragonal phase transformation. It is not clear whether the peak of the zirconia crystallization occurs close to $700-800^{\circ} \mathrm{C}$. Transformations related to silica formation and $\mathrm{ZrSiO}_{4}$ were not observed. This indicated that the amorphous phase of silica appears in a wide temperature range.

The X-ray diffraction pattern of powder of C3 concentration, Fig. 2, shows the tetragonal zirconia phase

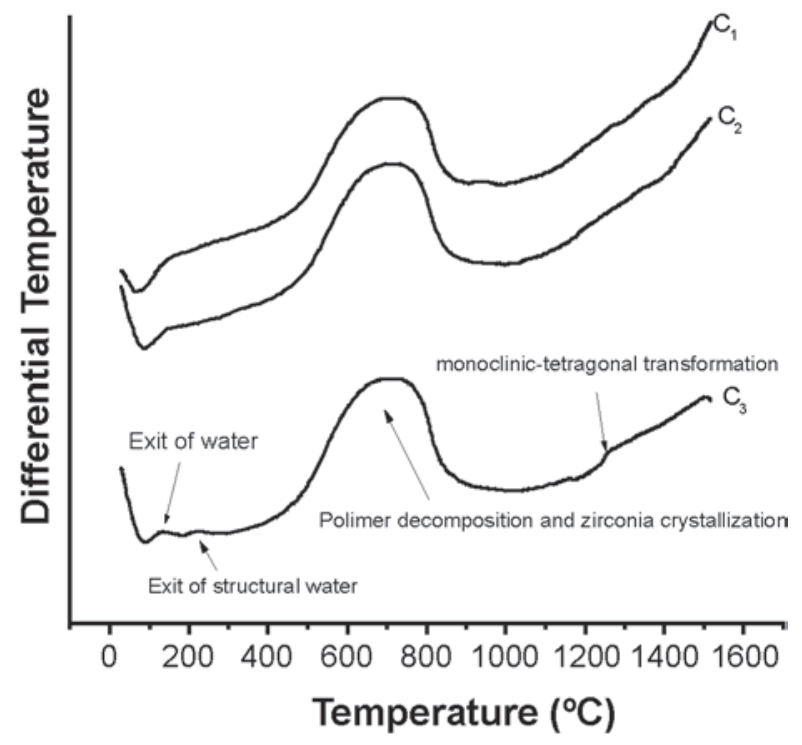

Figure 1: DTA curves of sample C1, C2 and C3.

[Figura 1: Curvas de DTA das amostras de composições C1, C2 e C3.]

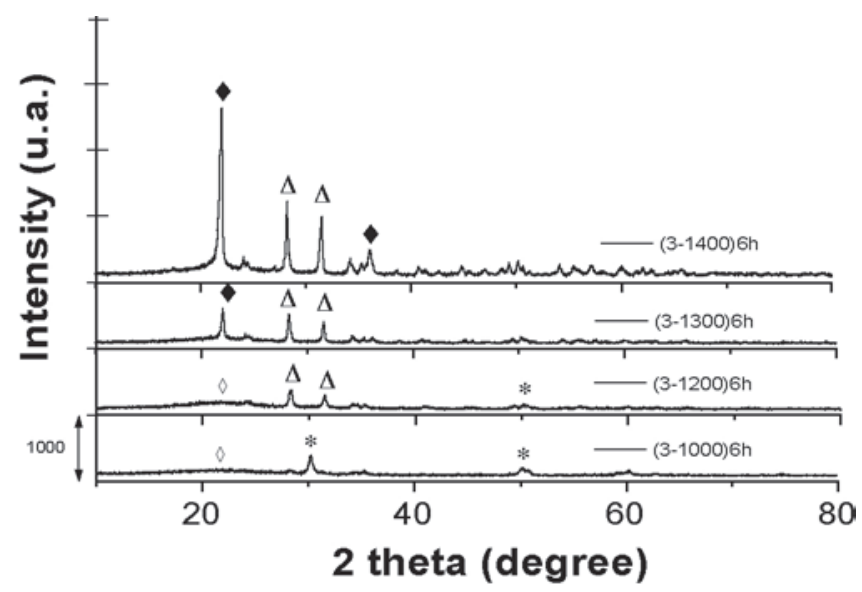

Figure 2: X-ray diffraction patterns of $\mathrm{C} 3$ powder.

[Figura 2: Difratogramas de raios X do pó de concentração C3.] 
formation at $1000{ }^{\circ} \mathrm{C} / 6 \mathrm{~h}$. The increase of temperature from $1200{ }^{\circ} \mathrm{C}$ to $1300{ }^{\circ} \mathrm{C}$ shows the formation of the monoclinic phase of the zirconia at $1200{ }^{\circ} \mathrm{C}$ and the monoclinic phase with a crystalline phase of crystobalite silica at $1300^{\circ} \mathrm{C} / 6 \mathrm{~h}$. The powder calcined at $1400{ }^{\circ} \mathrm{C} / 6 \mathrm{~h}$ shows the same pattern observed at $1300^{\circ} \mathrm{C} / 6 \mathrm{~h}$ with intense peaks. According to the phase diagram [8], above $1250{ }^{\circ} \mathrm{C}$ a phase based on $\mathrm{ZrO}_{2}$. $\mathrm{SiO}_{2}\left(\mathrm{ZrSiO}_{4}\right)$ is formed for all stoichiometric compositions. However the zircon phase was not observed showing separated phases for $\mathrm{ZrO}_{2}$ and $\mathrm{SiO}_{2}$.

Fig. 3 shows X-ray diffraction patterns of different compositions calcined at various times. The phase analysis of $\mathrm{C} 1$ and $\mathrm{C} 2$ compositions shows $100 \%$ of the tetragonal zirconia in the powder calcined at $1000{ }^{\circ} \mathrm{C}$. Intense peaks of stabilized zirconia phase were observed with formation of two different phases, tetragonal and cubic. A diffuse band of amorphous material related to silica shows that the crystalline phase was formed at temperatures above $1000{ }^{\circ} \mathrm{C}$.

Analysis by mapping the $\mathrm{K}_{\alpha}$ line of $\mathrm{Zr}, \mathrm{Si}$ and $\mathrm{O}$ of powder of $\mathrm{C} 2$ composition, Fig. 4, shows broad Si peaks and weak $\mathrm{Zr}$ peaks for all compositions. The $\mathrm{Zr}$ peak increases from $\mathrm{C} 1$ to $\mathrm{C} 3$ composition. The poor traces of $\mathrm{Zr}$ could indicate the presence of small concentration of $\mathrm{ZrO}_{2}$ particle in the powder. The spectra show a peak of carbon related to sample powder substrate in the three compositions.
Fig. 5 shows the scanning electron microscopy micrograph of the $\mathrm{C} 3$ concentration powder calcined at

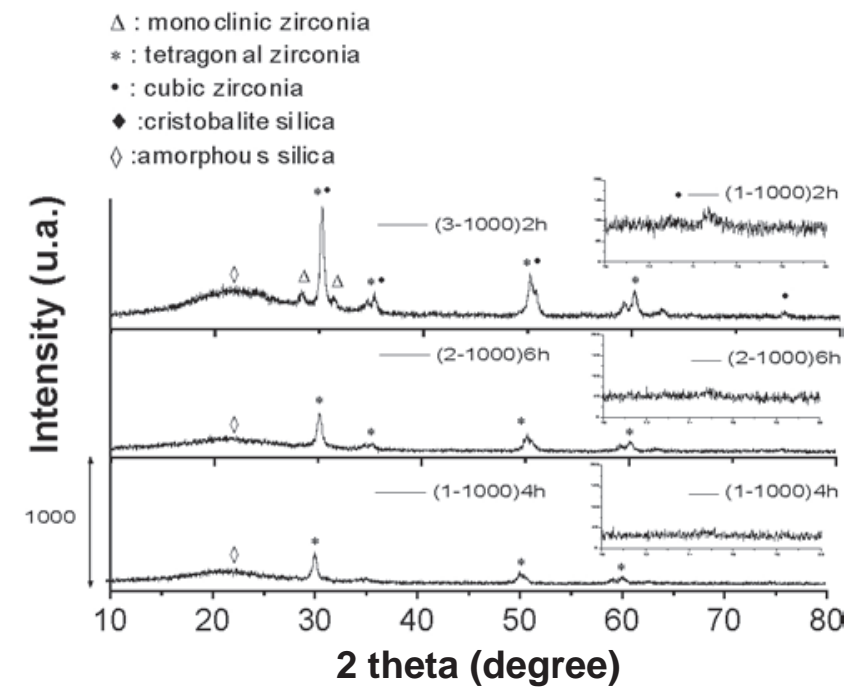

Figure 3: X-ray diffraction patterns of $\mathrm{C} 1, \mathrm{C} 2$ and $\mathrm{C} 3$ compositions with different times of calcination.

[Figura 3: Difratogramas de raios $X$ das composições $C 1$, $C 2$ e C3 com diferentes tempos de calcinação.] (a)

\section{Grey}

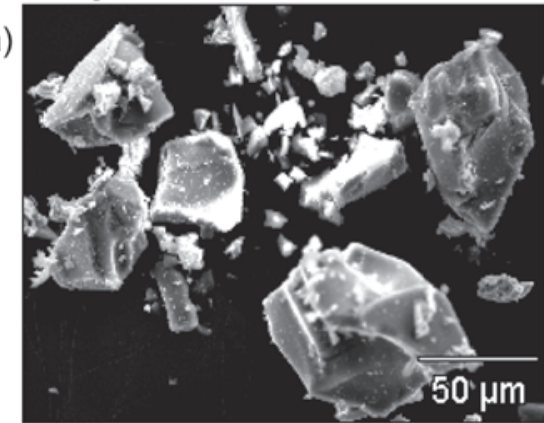

(c)
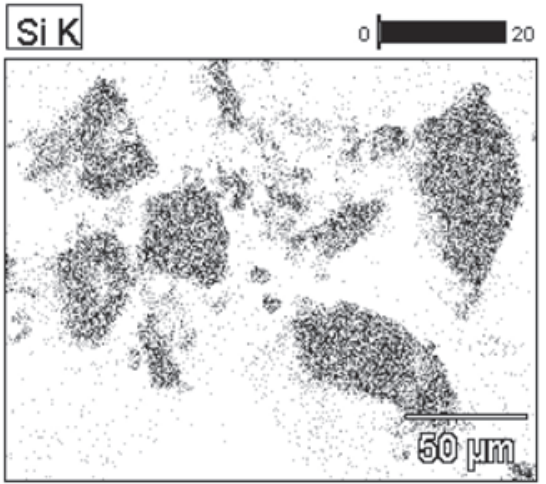

(b)

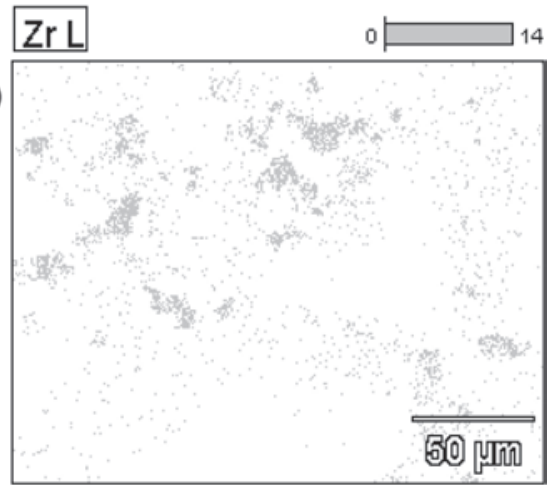

(d)

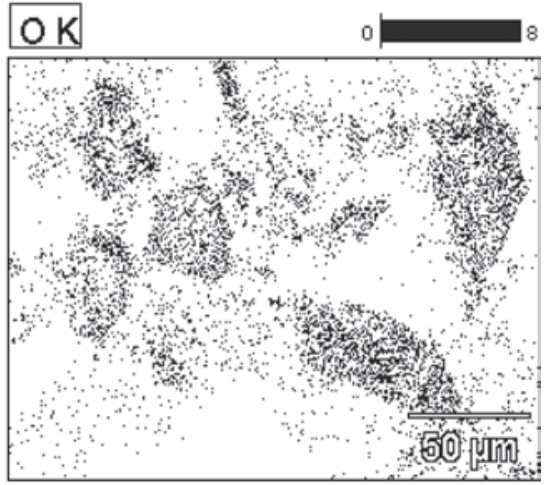

Figure 4: Scanning electron microscopy micrograph and microanalysis of C1 composition. a) SEM of powder, b) Zr mapping, c) Si mapping, d) O mapping.

[Figura 4: Microscopia eletrônica de varredura e microanálise da composição C1. a) MEV do pó, b) mapeamento do Zr, c) mapeamento do Si, d) mapeamento do O.] 

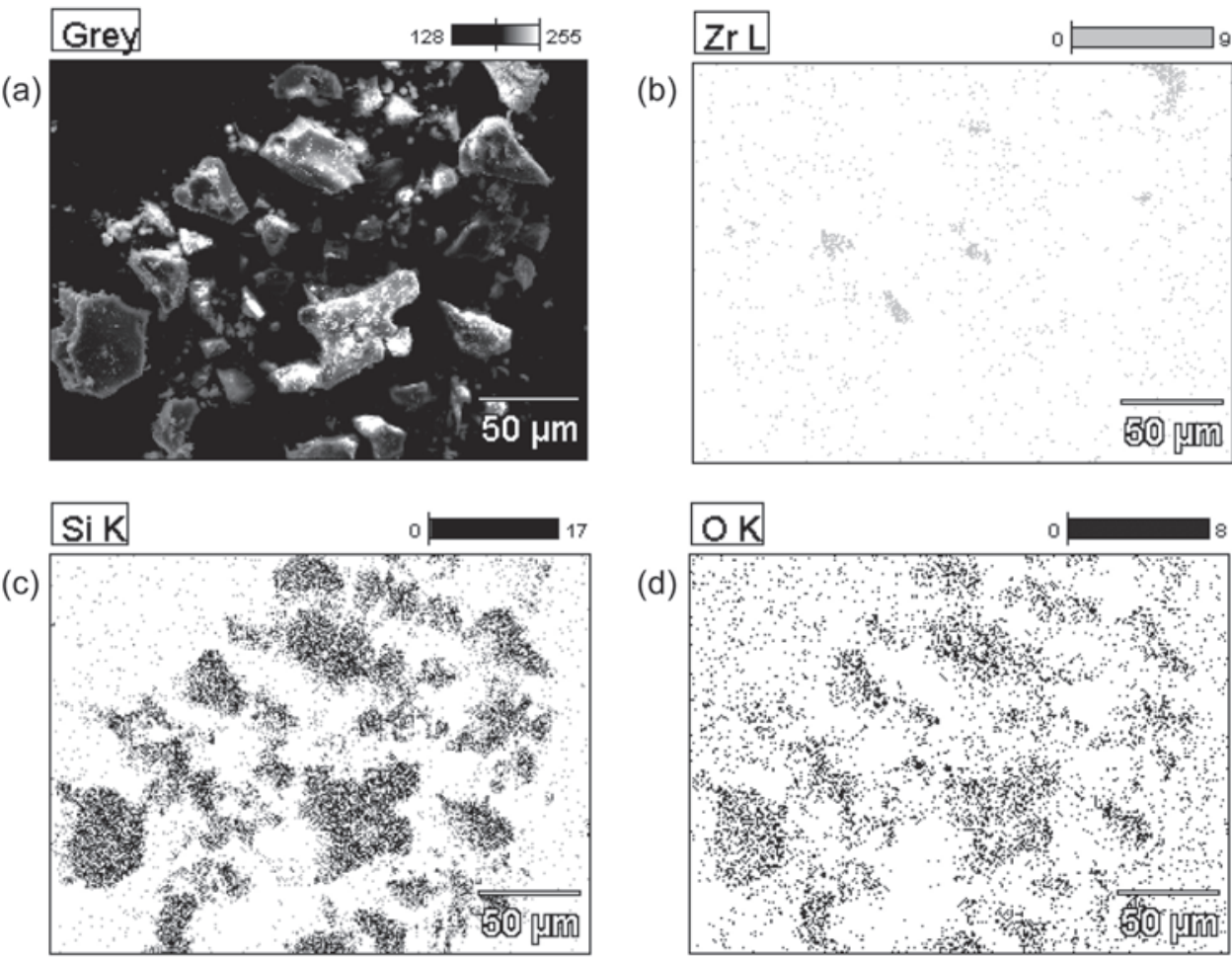

(d)

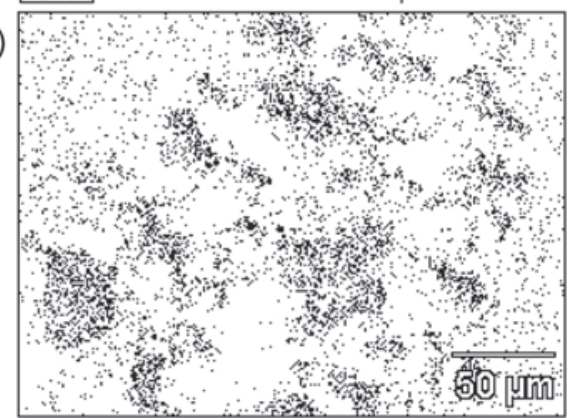

Figure 5: Scanning electron microscopy micrograph and microanalysis of C2 composition. a) SEM of powder, b) Zr mapping, c) Si mapping, d) O mapping.

[Figura 5: Microscopia eletrônica de varredura e microanálise da composição C2. a) MEV do pó, b) mapeamento do Zr, c) mapeamento do $\mathrm{Si}$, d) mapeamento do $\mathrm{O}$.
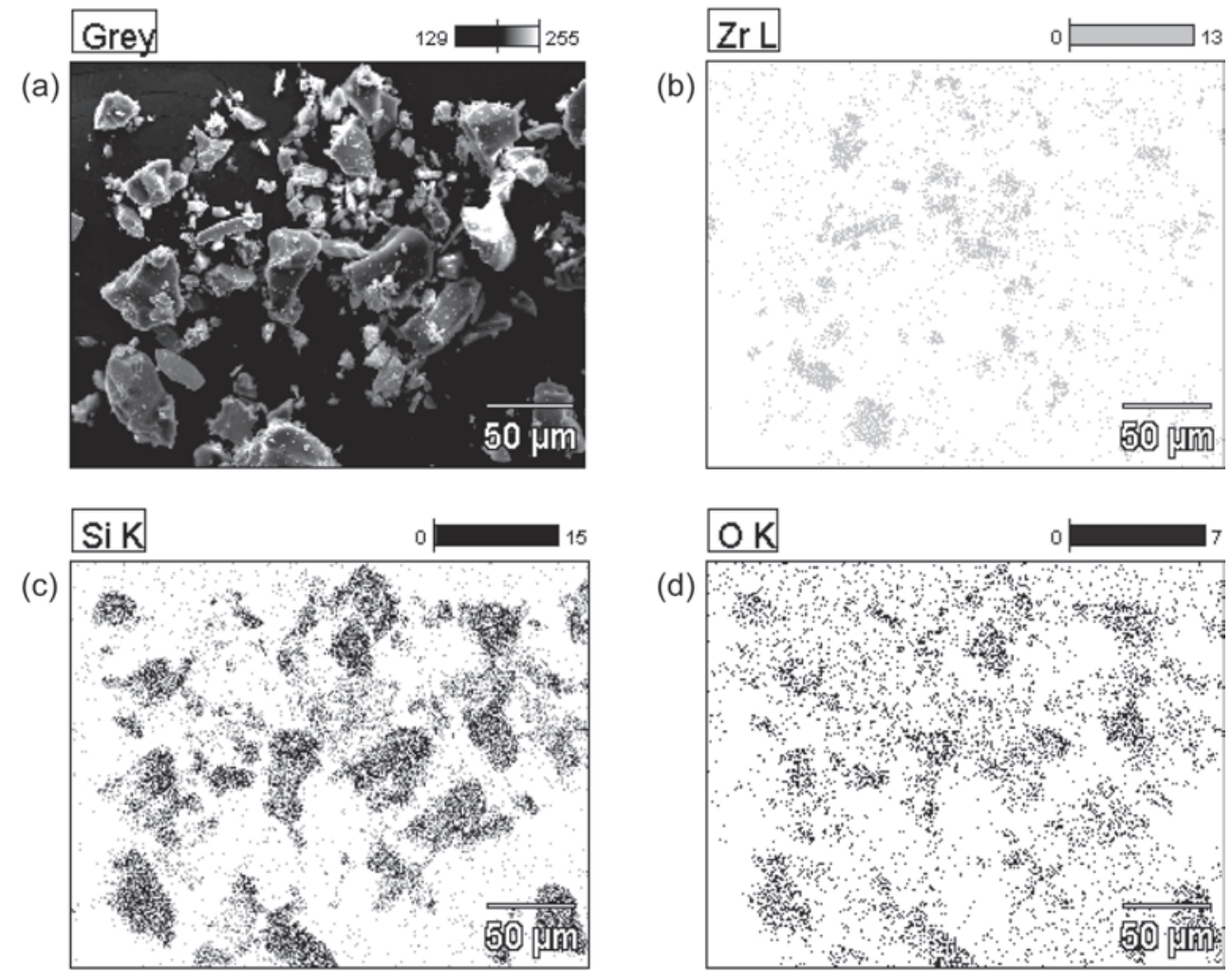

Figure 6: Scanning electron microscopy micrographs and microanalysis of C3 composition. a) SEM of powder, b) Zr mapping, c) Si mapping, d) O mapping.

[Figura 6: Microscopia eletrônica de varredura e microanálise da composição C3. a) MEV do pó, b) mapeamento do Zr, c) mapeamento do Si, d) mapeamento do O.] 

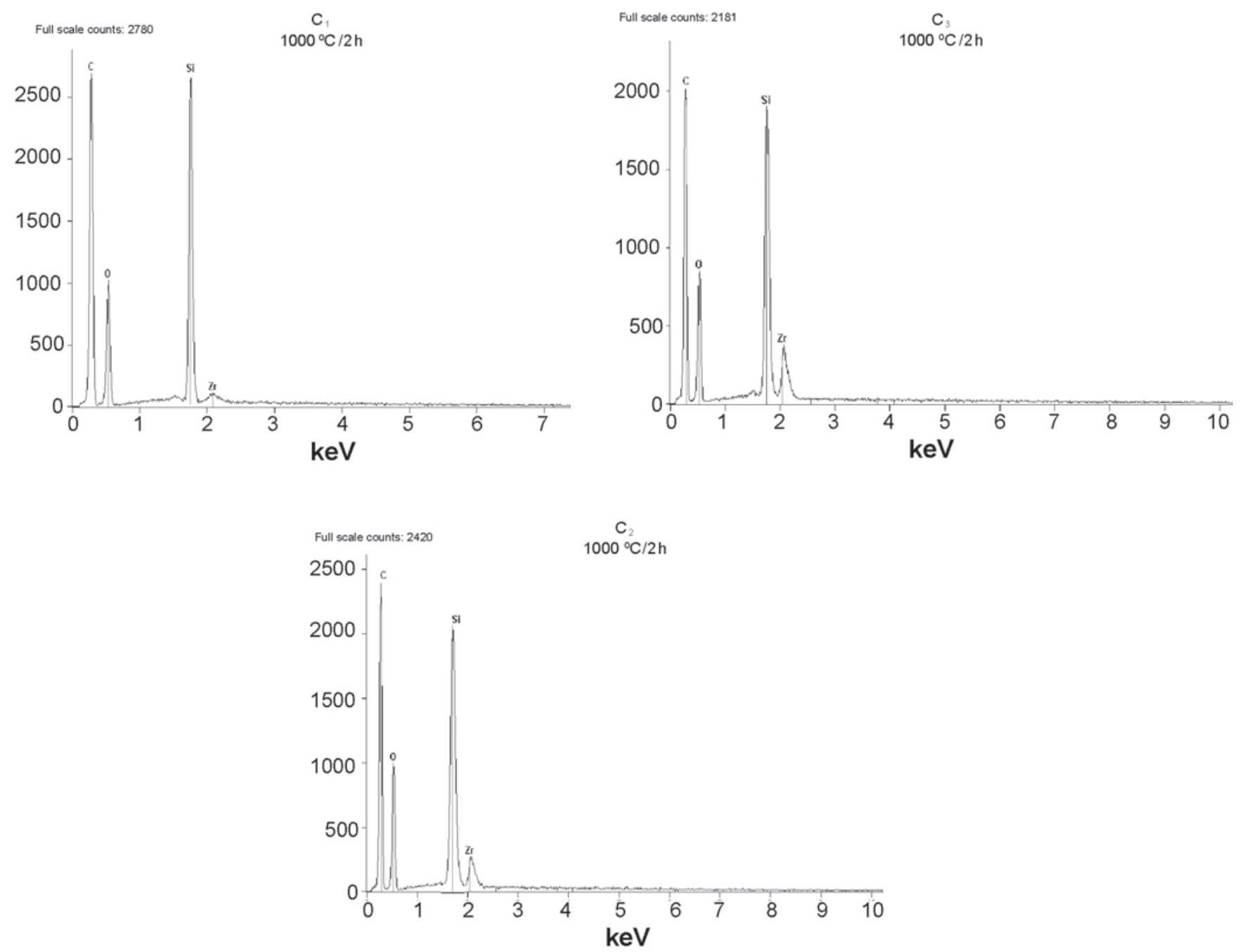

Figure 7: Spectra of mapping of $\mathrm{K}_{\alpha}$ line of $\mathrm{Zr}, \mathrm{Si}, \mathrm{O}$ and C. a) $\mathrm{C} 1$ composition, b) C2 composition, c) C3 composition. Powder calcined at $1000{ }^{\circ} \mathrm{C} / 2 \mathrm{~h}$.

[Figura 7: Mapeamento dos espectros das linhas $K_{\alpha}$ do $\mathrm{Zr}$, Si, O e C. a) composição C1, b) composição C2, c) composição C3. Pó calcinado em $1000^{\circ} \mathrm{C} / 2$ h.]

$1000{ }^{\circ} \mathrm{C}$. Particles in the $10-50 \mu \mathrm{m}$ range were observed indicating powder agglomeration. A mapping of the $\mathrm{K}_{\alpha}$ line of the powder indicated that there is a zirconia phase growth with the formation of microparticles and low frequency of distribution of particles. The analysis of the Si concentration shows a high frequency of particles forming macroparticles. According to the mapping data, low diffusion of zirconium and silicon ions takes place in $\mathrm{SiO}_{2}$ and $\mathrm{ZrO}_{2}$ particles, respectively. The $\mathrm{Si}$ distribution indicated low propagation into the zirconia particles without solid solution formation and $\mathrm{ZrSiO}_{4}$ phase formation. During decomposition of the polymeric resin individual nuclei of phases grows forming the crystalline phase of zirconia and the amorphous phase of silica. The cause of the different phase formation is the poor mixing between the precursors resin at molecular level. Several works indicated that the $\mathrm{ZrO}_{2}-\mathrm{SiO}_{2}$ mixture led to zircon phase formation.

Analysis by SEM of $\mathrm{C} 1$ powder, Fig. 6, shows macroparticle with size in the 5-60 $\mu \mathrm{m}$ range. The mapping of $\mathrm{K}_{\alpha}$ line shows an increase of $\mathrm{ZrO}_{2}$ particle frequency and a growth of particles relative to the powder of $\mathrm{C} 1$ concentration. The growth of zirconia particle does not led to dispersion of silicon into the $\mathrm{ZrO}_{2}$ structure. Substitution of silicon for zirconium positions into the lattice does not cause vacancies formation according to the reaction:

Silicon is isovalent relative to zirconium ion and has low diffusivity into the zirconia structure, the phase nucleates and grows in amorphous silica.

Analysis by scanning electron microscopy of powder with C3 concentration of zirconium, Fig. 7, shows a decrease of particle size of amorphous silica and an increase of particle frequency of zirconia demonstrating a particle growth relative to the powder of $\mathrm{C} 1$ and $\mathrm{C} 2$ concentrations. The X-ray diffraction pattern of the powder calcined at 1000 ${ }^{\circ} \mathrm{C}$ shows a decrease of the stabilized phase with formation of the monoclinic phase. This could indicate a limit of zirconia 
particle size for stabilization. The $\mathrm{K}_{\alpha}$ line mapping shows an increase of Si diffusion into the zirconia particle causing a decrease of zirconia stabilization considering that $\mathrm{Si}$ does not contribute to vacancy formation.

\section{CONCLUSIONS}

A complex polymer synthesized by using the Pechini method decomposes at different temperatures and times. Tetragonal zirconia was formed at $1000{ }^{\circ} \mathrm{C}$, monoclinic zirconia at $1200{ }^{\circ} \mathrm{C}$ and monoclinic zirconia and cristobalite silica in the $1300-1400{ }^{\circ} \mathrm{C}$ range. A diffuse amorphous band observed by X-Ray diffraction was formed from 1000 to $1300{ }^{\circ} \mathrm{C}$ relative to the silica phase. The increase of zirconia concentration led to the formation of fully tetragonal zirconia, TZP. A mapping of $\mathrm{Zr}$ and $\mathrm{Si} \mathrm{K}_{\alpha}$ line by EDS indicated the formation of small silica particles. The mapping of $\mathrm{K}_{\alpha}$ line of Si shows low propagation into the zirconia particles without solid solution formation. Such results demonstrated that the zirconia stabilization occurs without the influence of Si ions into the zirconia structure.

\section{REFERENCES}

[1] Y. Kanno, Suzuki, Estimation of formation mechanism of spherical fine $\mathrm{ZrO}_{2}-\mathrm{SiO}_{2}$ particle by ultrasonic spray pyrolysis, J. Mater. Sci. Lett. 7 (1988) 3067-3072.
[2] H. Kobayashi, T. Terasaki, T. Mori, H. Yamamura, T. Mitamura, Preparation of $\mathrm{ZrSiO}_{4}$ powders by sol-gel process (Part 3)- preparation conditions of $\mathrm{ZrSiO}_{4}$ composition precursor gels from $\mathrm{Si}\left(\mathrm{OC}_{3} \mathrm{H}_{7}\right)_{4}$ and $\mathrm{Zr}\left(\mathrm{OC}_{3} \mathrm{H}_{7}\right)_{4}$ alkoxydes, Seramikkusu Ronbunsshi 99, 1 (1991) 42-46.

[3] P. Tartaj, J. Sanz, J. Serna, M. Ocana, Zircon formation from amorphous spherical $\mathrm{ZrSiO}_{4}$ particles obtained by hydrolysis of aerosols, J. Mater. Sci. 29 (1994) 6533-6538.

[4] R. Valero, B. Durand, J. L. Guth, T. Chopin, Mechanism of hydrothermal synthesis of zircon, J. Sol-Gel Sci. Technol. 13 (1998) 119-122.

[5] J. Brinker, G. Scherer, Sol-Gel Science, Academic Press, San Diego, EUA (1985).

[6] T. Lopes, R. Gomez, in Sol-gel Optics: Processing and Aplications, Ed.: L. C. Klein, Kluwer, Boston, EUA 16 (1994) p. 345.

[7] C. Veytizou, J. F. Quinson, Y. Jorand, Preparation of zircon bodies from amorphous precursor powder synthesized by sol-gel processing, J. Eur. Ceram. Soc. 22 (2002) 29012909.

[8] D. H. Aguilar, L. C. Torres-Gonzales, L. M. TorresMartinez, A study of the crystallization in the sol-gel system: $\mathrm{ZrO}_{2}-\mathrm{SiO}_{2}$, J. Sol. State Chem. 158 (2000) 349-357.

[9] Y. Shi, X. Huang, D. Yan, Preparation and characterization of highly pure fine zircon powder, J. Eur. Ceram. Soc. 13, 2 (1994) 113-119.

(Rec. 15/05/2007, Rev. 12/11/2007, Ac. 14/12/2007) 